Avalaible online: https://ejournal.iai-tribakti.ac.id/index.php/pgmi

Article doi: https://doi.org/10.33367/jiee.v2i1.1077

\title{
Eksistensi Pendidikan Multikultural dalam Menghadapi Paham Radikalisme
}

\section{The Existence of Multicultural Education in Facing Radicalism}

\author{
Siti Ngaisah ${ }^{1}$ Yasin Nurfalah ${ }^{2}$ \\ 1,2Institut Agama Islam Tribakti Kediri, Indonesia \\ 1sitingaisahkdr@gmail.com; 2 Yasinfalach23@gmail.com
}

\begin{abstract}
This research, was born from a small part of anxiety over the understanding of radicalism in educational institutions. Many researchers claim that the spread of radicalism in Indonesia has been very acute, the article has spread to elementary students. Nevertheless, many are optimistic that multicultural education is one of the antidotes to the understanding of radicalism. This encourages researchers to assess the existence of multicultural education in facing radicalism in the Wanengpaten State Elementary School, Gampengrejo District, Kediri. This study uses a descriptive qualitative approach. The method used is, interviews with stakeholders at the institution, observing activities in implementting multicultural education values and tracking documents related to the educational institution. As a result, the key to counteract radicalism is religious understanding and awareness of the dangers of radicalism. Without it, the deradicalization program would not be possible.
\end{abstract}

Key Words: The Existence of Multicultural Education, Radicalism

\begin{abstract}
Abstrak
Penelitian ini, lahir dari bagian kecil kegelisahan mengatasi paham radikalisme di lembaga-lembaga pendidikan. Banyak peneliti menyatakan bahwa penyebaran radikalisme di Indonesia sudah sangat akut, pasalnya sudah menyebar pada peserta didik dasar. Meski demikian, banyak pula yang optimis bahwa pendidikan multikultural menjadi salah satu penangkal paham radikalisme. Hal ini, mendorong peneliti untuk mengakasi eksistensi pendidikan multikultural dalam menghadapi paham radikalisme di Sekolah Dasar Negeri Wanengpaten, Kecamatan Gampengrejo, Kabupaten Kediri, Penelitian ini menggunakan pendekatan kualitatif deskriptif. Metode yang digunakan adalah, wawancara kepada stakeholder pada lembaga tersebut, observasi kegiatan dalam implemantasi nilai-nilai pendidikan multikultural dan melacak dokumen-dokumen terkait lembaga pendidikan tersebut. Hasilnya, kunci menangkal radikalisme adalah
\end{abstract}


pemahaman keagamaan dan sadar bahaya radikalisme. Tanpa itu, program deradikalisasi tidak mungkin bisa dilaksanakan.

Kata Kunci: Eksistensi Pendidikan Multikultural, Radikalisme

\section{Pendahuluan}

Sejak menguatnya paham radikal di Sekolah Dasar, Pemerintah mencanangkan program pendidikan multikultural. Semangatnya, memantabkan karakter kebangsaan Indonesia yang berciri banyak suku, bangsa, agama dan budaya. Siswa didik mengakui perbedaan merupakan kekayaan, bukan menjadi alasan untuk melakukan permusuhan. Meski demikian sudah dimulai, akan tetapi tidak banyak Sekolah Dasar mampu menerapkan secara sempurna.

Tidak bisa dipungkiri, banyak peneliti dan pemerhati sosial menemukan penyebaran Islam radikal di Sekolah Dasar. Hasil penelitian Lembaga Kajian Islam dan Perdamaian (LaKIP) Jakarta pada Tahun 2014 menunjukkan fenomena tersebut. Sebanyak 48,9\% siswa di Jabodetabek menyatakan persetujuannya terhadap aksi radikal. Sebanyak itu pula, mereka menolak mengucapkan selamat hari besar penga-

1 Laporan Penelitian LKiP 2014 pada Abdul Munip, "Menangkal Radikalisme Agama di Sekolah", Jurnal Pendidikan Islam, vol 1. No. 2, (Desember, 2015). h. 14

2 Abu Rokhmad, "Radikalisme Islam dan upaya deradikalisasi paham radikal", Walisngo, vol. 20, no. 1, (Mei 2012).h.37

${ }^{3}$ Nur Syam, "Masih tentang Arah Baru Radikalisme" (http://nursyam.uinsby.ac.id/?p=2623), diakses pada 30 Januari 2019 nut agama lain, berdasarkan sentimen keagamaan. ${ }^{1}$ Ironisnya, mereka justru menyetujui tindakantindakan kekerasan atas nama agama Islam, misal sweeping tempat hiburan malam yang dilakukan oleh organisasi keagamaan (ormas) dan sejumlah penyerangan kegiatan ibadah yang dilakukan oleh kelompokkelompok yang disesatkan. ${ }^{2}$

Hasil penelitian Nursyam pun juga menegaskan, bahwa Sekolah Dasar sudah terpapar paham radikalisme. ${ }^{3}$ Ia menemukan bukti, bahwa anak-anak usia Sekolah Dasar sudah berani membakar pasport dan menantang Bangsa Indonesia untuk berperang. Kasus yang sangat mencengangkan adalah apa yang dilakukan Wildan, anak Paciran, Lamongan, Jawa Timur. Ia, tanpa berfikir panjang bergabung dengan ISIS dan melakukan bom bunuh diri. ${ }^{4}$ Dan tentu masih banyak anak-anak serupa dengan Wildan. Anak-anak

\footnotetext{
4 Zubadki, Zora A, "Kaum Muda dan Radikalisme" Jurnal Maarif, Vol. 8, No. 1 (Juli 2013): 14-41. Diakses dari http://maarifinstitute.org/ images/xplod/jurnal/vol\%20viii \%20no\%201\%20juli \%202013.pdf tanggal 30 Januari 2019.
} 
tersebut memutuskan menghapus masa bermain dengan haus darah.

Di Kabupaten Semarang, Jawa Tengah, beberapa tahun lalu sebuah yayasan pendidikan pernah memecat 13 guru karena mengajarkan paham radikal, seperti dijelaskan Ketua Yayasan Assalamah Ungaran, Husein Abdullah. ${ }^{5}$

"Memberikan pelajaran agama yang tidak sesuai syariat yang kami anut, mereka ini tidak sesuai dengan Syafi'i, mengajakan tak boleh tahlil, ziarah kubur, ini bapak-bapak kamu kalau tahlil itu salah dalam tanda kutip sekarang orang berbicara dengan istilah wahabi itu, mereka tak mau upacara bendera hari Senin, tak mau menyanyikan Indonesia Raya, setelah mereka masuk itu tidak ada," jelas Husein.

Fakta di atas, menunjukkan proses infiltrasi yang dilakukan aliran paham radikal berjalan dengan sangat baik. Menurut Eka Saputra, infiltrasi paham radikal di sekolah melalui banyak cara, termasuk bahan ajar Pendidikan Agama Islam (PAI). Seperti yang diungkapkan juga oleh Menteri Agama Fachrul Razi:

\footnotetext{
${ }^{5}$ Sri Lestari. "Ketika Paham Radikal Masuk ke Ruang Sekolah". BBC Indonesia (https://www.bbc.com/indonesia/berita_indonesi a/2016/05/160519_indonesia_lapsus_radikalisme anakmuda_sekolah/25 Mei 2016)

${ }^{6}$ Dian Mega. “Menag RI Identifikasi Tiga Jalan Radikalisme Menyusup ke Pendidikan". Times Indonesia (https://www.timesindonesia.co.id/read/news/24 el Bidayah: Journal of Islamic Elementary Education Volume 2, Number 1, March 2020
}

“ Pintu masuknya paham radi-kal ada 3 yakni melalui kurikulum pendidikan, kegiatan ekstrakurikuler di sekolah, dan melalui peran guru. Untuk itu, ia berpesan pada segenap guru PAI dan pengajar lain untuk senantiasa mengusung pelajaran Islam dengan nilainilai Islam yang rahmatan lil alamin." 6

Pendidikan multikultural pertama kali muncul dengan tujuan menuntut diperhatikannya hak-hak sipil. Gol utama dari gerakan ini adalah untuk melawan praktik diskriminasi terhadap kelompok minoritas. Multikulturalisme dalam praktiknya masuk ke dalam berbagai interaksi sosial di dalam kehidupan masyarakat. Gerakan ini ternyata juga berdampak pada dunia pendidikan. Aspek pendidikan dituntut menghasilkan program pendidikan dengan memperhatikan aspek-aspek etnik dan keragaman budaya. Sebagai sebuah ideologi, multikulturalisme harus diperjuangkan, karena kehadirannya sangat penting sebagai landasan bagi tegaknya keadilan dalam berbagai sektor kehidupan. ${ }^{7}$

3185/menag-ri-identifikasi-tiga-jalan-radikalismemenyusup-ke-pendidikan/14 Desember 2019) ${ }^{7}$ Ahsani Taqwiem. "Urgensi Pendidikan Karakter Berbasis Multikulturalisme". Disampaikan pada 1st International Conference on Social Sciences Education - "Multicultural Transformation in Education, Social Sciences and Wetland Environment", At Banjarmasin, Indonesia 2017 
Akar kata multikulturalisme adalah kebudayaan. Pengertian kebudayaan menurut para ahli sangat beragam, namun dalam konteks ini kebudayaan dilihat dalam perspektif fungsinya sebagai pedoman bagi kehidupan manusia. Dalam konteks perspektif kebudayaan tersebut, maka multikulturalisme adalah ideologi yang dapat menjadi alat atau wahana untuk meningkatkan derajat manusia dan kemanusiannya. ${ }^{8}$

Menanggapi fenomena tersebut, Kepala Sekolah Dasar Negeri (SDN) Wanengpaten, Kecamatan Gampengrejo Kabupaten Kediri berusaha mengantisipasinya. Salah satu strateginya, melaksanakan program pendidikan multikultural pada lingkungan sekolahnya. Dalam konteks inilah penelitian dilaksanakan.

\section{Metode}

Pendekatan dalam penelitian ini adalah pendekatan kualitatif. Dalam pendekatan ini diasumsikan akan memperoleh data penelitian berdasar perangkat penelitian kualitatif. Sedangkan jenis penelitiannya menggunakan metode kualitatif deskriptif, sebab dari hasil yang diperoleh peneliti berupa kalimat tertulis atau lisan dari informan. Penelitian ini, menjadikan peneliti sebagai instrumen kunci. Artinya, peneliti hanya tunduk dan patuh berdasarkan kebutuhan penelitian, bukan berdasarkan instrumen yang ditetapkan. ${ }^{9}$

Dalam menggali data, peneliti melakukan observasi kegiatan pelaksanaan pendidikan multikul-tural di SDN Wanengpaten. Selain itu, peneliti juga melakukan wawancara terhadap beberapa informan kunci, seperti Kepala Sekolah, Wakil Kepala Sekolah yang membidangi kurikulum dan guru Pendidikan Agama Islam (PAI). Pada saat bersamaan pula peneliti juga melakukan dokumen-tasi kegiatan dan melakukan analisis dokumen-dokumen yang mendukung tema penelitian ini. Penelitian dilakukan selama 2 bulan.

Setelah data terkumpul, peneliti melakukan analisis data, mengecek keabsahan data, dan menarik kesimpulan.

\section{Temuan dan Pembahasan Temuan penelitian}

Saat ini, kegiatan pembelajaran PAI di SDN Wanengpaten sama dengan kegiatan pembelajaran mata pelajaran lainnya. Penggunaan panduan menggunakan Kurikulum Tahun 2013 (K13).10 Berikut hasil penerapan kegiatan pembelajaran

\footnotetext{
${ }^{8}$ Parsudi Suparlan. "Menuju Masyarakat Indonesia yang Multikultural," Makalah. Disampaikan pada Simposium Internasional Bali ke-3, Jurnal Antropologi Indonesia, (Denpasar Bali, 16-21 Juli 2012), 30
}

${ }^{9}$ Mohamad Ali, Penelitian Kependidikan Prosedur \& Strategi (Bandung: Angkasa, 1987), h. 81.

10 Wawancara dengan Pak Jari (Kepala Sekolah SDN Wanengpaten) 
PAI yang diterapkan selama 5 tahun terakhir.

1. Perencanaan Sistem Pembelajaran PAI di SDN Wanengpaten Kecamatan Gampengrejo.

Secara umum, guru-guru di SDN Wanengpaten menyiapkan rencana kegiatan pembelajaran secara matang sebelum melakukan kegiatan belajar mengajar. Dalam penyusunan perencanaan pembelajaran untuk setiap pokok bahasan, langkahlangkah yang diterapkan selama ini adalah:

a. Menjabarkan atau menentukan kompetensi dasar;

b. Memilih bahan ajar;

c. Merencanakan kegiatan pembelajaran;

d. Menentukan media dan alat pembelajaran dan

e. Penyusunan evaluasi. ${ }^{11}$

Berikut adalah hasil wawancara dengan guru pendidikan agama Islam di SDN Wanengpaten mengenai perencanaan pembelajaran dalam pembuatan silabus pada mata pelajaran pendidikan agama Islam:

"Berkaitan dengan penyusunan silabus, saya melihat contohcontoh yang sudah ada dan panduan penyusunan silabus, selanjutnya dikembangkan sendiri. Silabus tersebut dijadikan acuan atau pedoman untuk membuat Rencana Pelaksanaan Pembe-lajaran (RPP). Didalam silabus dijelaskan mengenai standar kompetensi, kompetensi dasar, materi pembelajaran, kegiatan pembelajaran, indikator, penilaian, alokasi waktu, dan sumber belajar". 12

Selama ini, segala proses tahapan perencanaan dapat diselesaikan sebelum kegiatan pembelajaran dimulai. Meskipun seringkali keinginan itu tidak bisa diselesaikan atau diterapkan secara sempurna. Sebagai langkah antisipasi, rencana pembelajaran diterapkan dengan meminta bantuan dan arahan dari Kepala Sekolah, Pengawas Sekolah dan Ketua/Wakil Kurikulum.

Selanjutnya mengenai manfaat dari silabus beliau juga mengemukakan sebagai berikut:

"Manfaat dari silabus adalah sebagai pedoman dalam pengembangan pembelajaran lebih lanjut, seperti pembuatan Rencana Pelaksanaan Pembelajaran (RPP), pengelolaan kegiatan pembelajaran dan pengembangan sistem nilai".

Lebih jauh, dalam tahap perencanaan skema koordinasi guru Kepala Sekolah, Pengawas Sekolah dan Ketua/Wakil Kurikulum merumuskan hal-hal yang harus diper-

11 Dokumen RPP Guru Pendidikan Agama Islam (PAI) 2015, Dokumen tidak dipublikasikan. 
hatikan yang terumuskan dalam Standart Operational Prosedur (SOP). Berikut contoh SOP yang tersusun sebagai panduan pada pembelajaran Tahun Ajar 2017-2018.

a. Menguasai silabus;

b. Menyusun Analisis Materi Pelajaran (AMP);

c. Menyusun program semester;

d. Menyusun rencana pembelajaran.

e. Menyusun strategi dan target pengelolaan kelas dalam setiap kelasnya.

f. Merumuskan hadiah dan hukuman bagi siswa-siswa berdasarkan tingkat kesalahan.

g. Menyusun model bimbinan di luar kegiatan belajar mengajar kelas.

Dalam kegiatan awal inilah, pertimbangan menerapkan nilainilai multikultural harus diterapkan. Sejatinya, SOP koordinasi perencanaan pembelajaran sudah ditetapkan oleh Kepala Sekolah. Hal ini untuk memastikan, semua guru melakukan kewajibannya secara profesional. ${ }^{13}$

\section{Pelaksanaan Sistem Pembelajaran} PAI SDN Wanengpaten

Pelaksanaan pembelajaran sangat erat kaitannya dengan peran guru PAI dalam pembelajaran di kelas. Dalam pelaksanaan pembe- lajaran yang berhasil diidentifikasi meliputi pengorganisasian pembelajaran dan kepemimpinan seorang guru dalam proses pembelajaran di kelas. Pengorganisasian pembelajaran yang dilakukan oleh guru PAI meliputi pembagian tugas kepada peserta didiktentang hal-hal yang harus dilakukan selama proses pembelajaran dan tujuan yang akan dan harus dicapai melalui pembelajaran tersebut. ${ }^{14}$

Dalam proses pembelajaran guru mampu menerapkan sebagai pemimpin berperan dalam mempengaruhi atau memotivasi peserta didik. Selama ini yang dilakukan adalah melalui penyajian pelajaran yang menarik dan hubungan pribadi yang menyenangkan baik dalam kegiatan belajar di dalam kelas maupun di luar kelas. Pengelolaan kelas dilakukan sesuai dengan kebutuhan dan latar bela-kang peserta didik yang berbeda-beda hanya saja penataan meja kursi masih menggunakan pola konvensional dimana guru menjadi pusat proses pembelajaran dan peserta didik sebagai subjek pendidikan. ${ }^{15}$

Menurut guru PAI SDN Wanengpaten, tujuan pengelolaan kelas adalah agar setiap anak di kelas dapat bekerja dengan tertib sehingga tujuan pengajaran terca-pai

\footnotetext{
${ }^{13}$ Dokumen Raker Tahunan 2017 SDN Wanengpaten 2019, Dokumen tidak dipublikasikan

${ }^{14}$ Dokumen Kegiatan belajar Mengajar SDN Wanengpaten Kab, Kediri

15 Observasi Tahun ajaran Baru 2019- 
secara efektif dan efisien. Guru sangat berperan dalam pengelolaan kelas, apabila guru mampu mengelola kelasnya dengan baik maka tidaklah sukar bagi guru itu untuk mencapai tujuan yang telah dirumuskan. Pada fase ini pula, guru menerapkan nilai-nilai dalam pendidikan multikultural misalnya memperlakukan sama kepada semua siswa. Bersikap saling menghormarti dan saling tolong menolong terhadap sesama teman.

Pendekatan pembelajaran yang dilakukan oleh SDN Wanengpaten dalam penyampaian materi sudah baik, adapun media yang digunakan juga bervariasi seperti sarana ibadah, buku-buku, alat peraga, dan sebagainya, sehingga dapat mendukung berjalannya proses pembelajaran.. ${ }^{16}$

Beberapa metode yang dipakai dalam melakukan pembelajaran PAI di SDN Wanengpaten, sebagaimana diungkapkan oleh guru PAI sebagai berikut:

"Dalam menggunakan metode, semua itu tergantung materi yang diajarakan dan yang biasa saya pakai yaitu, ceramah, tanya jawab, penugasan, tugas kelompok dan demonstarsi, namun semua itu tergantung materi yang akan diajarkan dan terkadang saya juga tidak Agama Islam (PAI) 2015, Dokumen tidak dipublikasikan
16 Dokumen RPP Guru Pendidikan

selalu memakai ceramah, agar para siswa tidak bosan".17

Sedangkan salah satu siswa mengatakan bahwa

"Guru menggunakan cara belajar dengan didahului ceramah, setelah itu Saya diminta untuk mengerjakan soal-soal, terkadang juga tugas kelompok dan demonstrasi."18

Untuk memperkuat hasil wawancara tersebut peneliti melakukan observasi didalam kelas guna melihat proses pembelajaran pendidikan agama Islam yang ada di kelas. Peneliti ke lokasi penelitian bahwa seorang guru sedang mengajar dengan menggunakan metode yang bervariasi. Hasil observasi tersebut menunjukkan bahwa guru memakai bermacam-macam metode dalam menyam-paikan materi kepada peserta didik. Sebagai penguat bahwa siswa-siswi benar-benar berinteraksi dengan baik sehingga dapat meningkatkan motivasi belajar siswa. Hal tersebut diperkuat dengan file note berikut:

"Beliau terlihat menggunakan metode bermacam-macam, seperti ceramah, diskusi dan penugasan. Hal tesebut berguna untuk menghindari kejenuhan para siswa dalam proses pembelajaran tersebut dan mempermudah pemahaman siswa terhadap materi.

17 Wawancara dengan Pak Jari, Kepala sekolah SDN Wanengpaten

18 Wawancara dengan Wakil Kurikulum SDN Wanengpeten

el Bidayah: Journal of Islamic Elementary Education Volume 2, Number 1, March 2020 
Hal tersebut terbukti semangat para siswa bertanya sesuatu yang tidak dimengerti terhadap materi yang sedang dipelajari". ${ }^{19}$

Dari berbagai hasil wawancara dan hasil observasi di atas, dapat disimpulkan bahwa guru memakai bermacam-macam metode dalam melakukan pembelajaran untuk menghindari kejenuhan para siswa dalam proses pembelajaran. Hal tersebut digunakan untuk pengenalan siswa pada materi sebagai modal melakukan interaksi pada saat pembelajaran sehingga siswa memiliki dorongan untuk menanyakan materi yang belum dimengerti, sehingga siswa mempunyai keinginan untuk benar-benar mengikuti pelajaran yang sedang dipelajari.

\section{Proses Evaluasi.}

Evaluasi pembelajaran yang dilakukan SDN Wanengpaten untuk mengetahui capaian tujuan pembelajaran sesuai dengan acuan pelaksanaan evaluasi pembelajaran. Karena SDN Wanengpaten menggunakan K13 maka standar yang digunakan adalah evaluasi yang ditetapkan berdasarkan K13. Dalam Kurikulum Tingkat Satuan Pendidikan (KTSP) yang terdiri dari evaluasi belajar dan evaluasi proses pembelajaran. Evaluasi hasil belajar yang dilaksanakan oleh guru PAI telah sesuai dengan evaluasi hasil belajar yang terdapat dalam KTSP, yakni penilaian berbasis kelas yang memuat ranah kognitif, psikomotorik dan afektif. Hal yang perlu diperhatikan dalam penilaian adalah prinsip kontinuitas, yaitu peserta didik secara terus menerus mengikuti pertumbuhan, perkembangan dan perubahan peserta didik dalam pembelajaran.

\section{Penanaman Nilai-Nilai Multikultural Melalui Narasi}

Sejatinya, penyelenggara pendidikan di SDN Wanengpaten menyadari pentingnya menanamkan nilainilai multikultural, akan tetapi secara konsep belum memahami secara utuh. Mereka menyusun dan menetapkan yang berupaya melestarikan keragaman budaya bangsa yang majemuk menjadi pemersatu bangsa Indonesia. Kesadaran ini sudah muncul sebelum menguatnya gerakan radikalisme.

Pak Jari berkata, "Sebelum adanya gerakan radikalisme atau apalah mbak ya, kita sudah menyadari tentang pentingnya menjaga keutuhan NKRI. Dan memang itu juga sudah ada sejak SDN Wanengpaten menyelenggarkan pendidikan."20

Pelaksanaan pendidikan multikultural di SDN Wanengpaten meng-

19 Wawancara dengan Pak Jari, Kepala sekolah SDN Wanengpaten

20 Wawancara dengan Pak Jari, Kepala SDN Wanengpaten

el Bidayah: Journal of Islamic Elementary Education Volume 1, Number 2, March 2020 
akulturasikan pada kesadaran dan pengakuan serta penerimaan sikap, perilaku, mental, dan moral warga sekolah yang dilaksanakan dalam berbagai kegiatan. Contoh kecil adalah penegasan tentang pengakuan teman sekolah yang beragama non muslim. Pengakuan itu diwujudkan dengan sikap saling menghargai dan menghormati, dan saling berkunjung ke rumah. Mekipun demikian, bukan berarti anak-anak dibiarkan ikut melaksanakan kegiatan ibadah agama lain. Hal ini tetap perlu dicegah, karena akan menimbulkan sikap sarkatisme atau mencampuradukkan keyakinan.

Segala kegiatan tersebut juga masuk dalam penilaian guru dalam menentukan nilai karakter siswa. Penilaian pendidikan multikultural di SDN Wanengpaten dengan indikator berupa perubahan perilaku sikap, moral, dan mental serta pandangannya tentang keberagamanan sosial, budaya dan agama. Indikator tersebut sebagai bahan untuk mengembangkan pada diri seseorang tiga aspek dalam kehidupannya, yakni, pandangan hidup, sikap hidup dan keterampilan hidup.

Upaya untuk mengembangkan ketiga aspek tersebut bisa dilaksanakan di sekolah, luar sekolah dan keluarga. Kegiatan di sekolah direncanakan dan dilaksanakan secara ketat dengan prinsip-prinsip yang sudah ditetapkan. Pelaksanaan di luar sekolah, meski memiliki rencana dan program yang jelas tetapi pelaksanaannya relatif longgar dengan berbagai pedoman yang relatif fleksibel disesuaikan dengan kebutuhan dan kondisi lokal. Pelak-sanaan pendidikan dalam keluarga dilaksanakan secara informal tanpa tujuan yang dirumuskan secara baku dan tertulis.

\section{PEMBAHASAN}

Dalam melaksanakan penyelenggaraan pendidikan, SDN Wanengpaten mengikuti tujuan pendidikan nasional. Menurut Kepala Sekolah SDN Wanengpaten, Tujuan pendidikan nasional adalah menciptakan perserta didik agar menjadi manusia yang beriman, bertakwa kepada Tuhan Yang Maha Esa dan mempubnyai jiwa Nasionalisme. Hal ini sesuai dengan sosialisasi dalam bimbingan teknis kurikulum yang dilaksanakan oleh Departeman Pendidikan dan Kebudayaan (Depdikbud) Kabupaten Kediri. Tujuan ini dianggap sangat tinggi, sehingga banyak sekolah-sekolah bekerja keras untuk mewujudkannya.

Dalam panduan penyelenggaraan pendidikan SDN Wanengpaten, tujuan tersebut diturunkan dalam berbagai indikator, diantaranya, berakhlak mulia, sehat, berilmu, cakap, kreatif, mandiri, dan menjadi warga Negara yang demokratis serta bertangnggung jawab. Dampaknya, segala bahan ajar materi pembela- 
jaran harus dirancang untuk mencapai tujuan tersebut. Termasuk didalamnya materi pembelajaran Pendidikan Agama Islam (PAI).

Begitu beratnya tanggung jawab tersebut, PAI juga harus membentengi peserta didik dari ajaran-ajaran radikalisme. Terkait dengan maraknya tindakan radikalisme beragama dikalangan siswa tentu tidak sematamata disebabkan oleh faktor tunggal. Radikalisme tidak serta merta muncul karena sifat pembawaan lahir, atau karena kesalahan dalam proses pendidikan agama. Radikalisme ada karena sebab yang multi dimensi seperti karena pengaruh persoalan politik, ekonomi, ketidakadilan sosial, dan dimungkinkan karena pengaruh ideologi/faham keagamaan global.

Pak Jari berkata, "Yang saya tahu, sebenarnya penyebab radikalisme itu sangat banyak. Mungkin ya, yang saya tahu dari media itu, misalnya pengaruh politik, pengaruh informasi media sosial, ekonomi, karena kita sering melihat orang-orang yang ikut demo misalnya ada yang karena di bayar, berarti kan mereka butuh pemasukan, karena kecewa dengan sistem politik di Indonesia dan lain sebagainya."

Lingkungan di luar sekolah, faktor yang lebih banyak mempengaruhi pemahaman radikalisme. Pendidikan merupakan bagian kecil dari faktor yang membentuk perilaku seoarang anak. Anak-anak SDN Wanengpaten, rata-rata tinggal di lingkungan yang keagamaan kuat, maka informasi keagamaan yang di dapat lebih banyak dari lingkungan. Di sekolah sangat minim, karena dalam satu minggu anak-anak hanya satu jam pelajaran agama dengan durasi sekitar 35 menit.

"Pelajaran agama yang didapatkan anak-anak sangat minim di sekolah, karena di SDN kami dalam seminggu hanya dua jam pelajaran dengan durasi perjamnya 35 menit," kata Sularti S.Pd.I

Berdasarkan itu, pihak SDN Wanengpaten berpendapat seorang anak meski tidak mendapatkan pendidikan agama di sekolah kurang memadai, tetapi hidup dalam lingkungan yang baik, maka dapat dimungkinkan akan memiliki perilaku yang baik. Terlebih, secara umum masyarakat Desa Wanengpaten berpaham keagamaan moderat yaitu ahlusunnah wal jamaah. "Kita tahu bersama, masyarakat Desa Wanengpaten itu berpaham ahlussunnah waljamaah atau NU," kata Pak Jari.

Oleh karena itu, menurut Pak Jari mencari sumber munculnya gerakan radikal dalam beragama dengan hanya melihat pada sumber bacaan siswa merupakan langkah kecil dari upaya untuk melihat sebuah potensi kemungkinan munculnya tindakan radikal dari sebab di satu sisi saja. Pada sisi yang lain tentu masih banyak faktor yang bisa mempenga- 
ruhi sesorang anak melakukan sebuah tindakan kekerasan atas nama agama. Bagaimana peran guru dalam memberikan penjelasan, peran orang tua, pengaruh lingkungan pertemanan, dan juga pengaruh dari media innformasi lainnya, ikut menentukan sikap dan tindakan seorang anak. Hal ini yang harus dilihat secara komperhensif.

Betapapun demikian, penelitian ini menemukan faktor kuat indikasi penyebaran ideologi radikalisme meskipun sangat kecil. Dari hasil penggalian data, secara teknis, ketiga buku PAI yang dikeluarkan oleh penerbit nampak telah memenuhi standar isi yang dikeluarkan oleh Kementerian Pendidikan Nasional mengandung unsur-unsur ideologi radikalisme. Contohnya, dalam Buku xxxxx Agama Islam untuk Sekolah Dasar kelas III, Penerbit B, No ISBN 978-XXX-01X-015, Buku xxxxx Agama Islam untuk Sekolah Dasar kelas IV, Penerbit B, No ISBN 978XXX-01X-016-4, dan Buku xxxxx Agama Islam untuk Sekolah Dasar kelas V, Penerbit B, No ISBN 978XXX-01X-017.

Dalam buku-buku tersebut, menjelaskan tentang konsep pemikiran pemerintahan khulafaur rosyidin, sistem kerajaan atau khilafah. Sejatinya, sekilas dapat dilihat materi tersebut tidak bermuatan ideologi radikal. Akan tetapi jika penyampaian atau penjelasan guru tidak cukup memadai, akan berpotensi membangun kesadaran peserta didik tentang ideologi khilafah. Karena dalam mata pelajaran tersebut hanya disebutkan keberhasilan-keberhasilan pemerintahan khulafaurrosyidin, tidak mengungkap kelemahan atau kekurangannya.

Berbeda dengan materi lain tentang penanaman akhlak terhadap sesama manusia. Buku itu menjelaskan dengan baik tentang konsep tolong menolong. Menurut Kepala Sekolah merangkap juga sebagai pengawas menjelaskan, konsep tolong menolong yang ada di pelajaran PAI SDN Wanengpaten masih mencontoh relasi homogen antar umat Islam. Meskipun demikian, guru dituntut menjelaskan tentang konsep hubungan manusia secara sempurna. Tidak hanya satu agama akan tetapi berbeda agama, suku dan perbedaanperbedaan lainnya.

Pak Jari berkata, "Kita menyadari memang dalam buku pelajaran PAI tersebut, hubungan baik dalam tolong menolong yang dibangun hanya satu golongan atau satu agama saja, akan tetapi guru agama harus bisa menjelaskan di sekeliling kita banyak penganut agama lain termasuk teman-teman sekolahnya. Meskipun tidak banyak, ada satu, dua orang yang non muslim."

Lebih jauh, SDN Wanengpaten juga fokus dalam gerakan radikalisme. Menurut Ibu, Sularti, bukubuku PAI memenuhi tuntutan kurikulum yang di tetapkan oleh 
pemerintah. Akan tetapi, tema-tema materi yang diusung menunjukkan masih sebatas pada pengetahuan tentang ajaran agama yang membangun kesalehan personal seperti materi tentang fiqh ibadah, kemampuan baca dan tulis Al-Qur'an, pengetahuan tentang ajaran tauhid, sejarah Islam, dan akhlak. Sementara itu tema-tema akhlak sendiri masih sangat universal, belum mengarah pada pembentukan kepribadian yang plural dan menghormati perbedaan keyakinan agama. Tema-tema akhlak yang disampaikan dalam buku PAI secara umum yaitu bertemakan tentang sabar, ikhlas, hemat, tekun dll.

Nilai-nilai moral yang sangat dibutuhkan dalam menghadapi radikalisme beragama yaitu bagaimana menyikapi perbedaan keyakinan sebagai sebuah berkah, yang diberikan Tuhan. Agama hadir tidak dalam rangka menciptakan perbedaan dan permusuhan, tetapi sebagai rahmat yang membangun jalan kedamaian. Ajaran moral keagamaan yang ditumbuhkan adalah untuk mengarahkan pemeluk beragama hidup berdampingan secara damai, bekerjasama dalam membangun kehidupan sosial. Tidak sebaliknya, menonjolkan pemahaman ajaran keagamaan tertentu secara doktrinal, memberikan klaim kebenaran sendiri, tidak mengakui kebenaran agama lain.

\section{Kesimpulan}

Hasil kajian penelitian ini menunjukkan, ada kesadaran dari Kepala Sekolah dan Guru PAI Sekolah Dasar Negeri (SDN) Wanengpaten, Kecamatan Gampengrejo, Kabupaten Kediri. Terbukti, mereka menjadikan penididikan multikultural untuk menangkal paham radikalisme pada siswa-siswanya. Nilai-nilai multikultural diterapkan pada semua kegiatan sekolah, misalnya kegiatan belajar mengajar, upacara, kegiatan amal dan lain sebagainya.

\section{Daftar Pustaka}

Abdul Munip, "Menangkal Radikalisme Agama di Sekolah", Jurnal Pendidikan Islam, vol 1. No. 2, (Desember, 2015)

Lestari, Sri. "Ketika Paham Radikal Masuk ke Ruang Sekolah". BBC Indonesia (https://www.bbc.com/i ndonesia/berita_indonesi a/2016/05/160519_indo nesia_lapsus_radikalisme_ anakmuda_sekolah/25 Mei 2016)

Mega, Dian. "Menag RI Identifikasi Tiga Jalan Radikalisme Menyusup ke Pendidikan". Times Indonesia (https://www.timesindo nesia.co.id/read/news/2 43185/menag-riidentifikasi-tiga-jalanradikalisme-menyusup- 
ke-pendidikan/14

Desember 2019)

Ali, Muhammad. "Penelitian

Kependidikan Prosedur \&

Strategi".

(Bandung:

Angkasa, 1987), h. 81.

Nur Syam, "Masih tentang Arah

Baru Radikalisme"

(http://nursyam.uinsby.a

c.id/?p=2623), diakses

pada 30 Januari 2019

Suparlan, Parsudi. "Menuju

Masyarakat Indonesia

yang Multikultural,"

Makalah. Disampaikan

pada Simposium

Internasional Bali ke-3,

Jurnal Antropologi

Indonesia, (Denpasar Bali, 16-21 Juli 2012),

Taqwiem, Ahsani. "Urgensi

Pendidikan Karakter

Berbasis

Multikulturalisme".

Disampaikan pada 1st

International Conference

on Social Sciences

Education - "Multicultural

Transformation in

Education, Social Sciences

and Wetland

Environment", At

Banjarmasin, Indonesia 2017

Zubadki, Zora A, "Kaum Muda dan Radikalisme" Jurnal Maarif, Vol. 8, No. 1 (Juli 2013): 14-41. Diakses dari http://maarifinstitute.org /images/xplod/jurnal/vo 1\%20viii\%20no\%201\%2 0juli\%202013.pdf tanggal 30 Januari 2019. 
Eksistensi Pendidikan Multikultural dalam ...

Oleh: Siti Ngaisah ${ }^{1}$, Yasin $\mathcal{N}$ urfalah ${ }^{2}$

This page intentionally left blank 